\title{
Manajemen Kualitas Aset Produktif Dan Pengaruhnya Terhadap Laba Bank Pada Bank Perkreditan Rakyat di Indonesia
}

\author{
Hesti Budiwati \\ STIE Widya Gama Lumajang \\ Email: hestibudiwati1404@gmail.com
}

\begin{abstract}
Managing the bank risk well are very needed so that the bank can operate smoothly. One of the important bank risk to managed well is bank asset quality risk. The banks are required to be careful and wiser in manage these asset quality risk. The object of this study is to obtain evidence of the effect of productive asset quality management on bank profit. The empirical studies conducted on rural banks in Indonesia. As the independent variable is productive asset quality consist of classified productive asset, productive asset quality and non-performing loan, while as the dependent variable is bank profit measured by return on asset. Return on asset of 89,6\% explained by classified productive asset, productive asset quality and non-performing loan. While the rest return on asset of 10,4\% effect by other variables that not examined in this study.

Keywords: Classified Productive Asset, Productive Asset Quality, Non-performing Loan, Return on Asset.
\end{abstract}

\section{Pendahuluan}

Mengelola risiko perbankan dengan baik sangat dibutuhkan agar bank bisa beroperasional dengan lancar. Risiko kualitas asset merupakan jenis risiko di bank yang penting untuk dikendalikan dengan baik. Bank harus menerapkan prinsip hati hati dan bijaksana pada saat mengelola risiko kualitas aset ini. Seperti diketahui bersama bahwa ada dua bank yang berbeda dari segi ruang lingkup kegiatannya di Indonesia yaitu Bank Umum dan BPR. Perbedaaan ini selain terletak pada ruang lingkup kegiatan operasionalnya, juga wilayah operasionalnya. BPR terbatas pada kegiatan mengumpulkan dana dari nasabah dan hanya diperkenankan memberikan dananya kembali berbentuk pinjaman. Sangat dibutuhkan kemampuan mengelola kualitas aset produktif pada jenis BPR berupa pemberian pinjaman ke masyarakat dimana pihak manajemen BPR harus bisa menjaga pinjaman yang diberikan tetap bisa sehat dan menghasilkan agar tidak terjadi kerugian. Dimana kerugian yang bisa berujung pada kepailitan ini 
bisa terjadi diantaranya jika tidak diterapkan prinsip kehati-hatian. Posisi kredit yang tinggi tetapi jika kreditnya banyak yang tidak sehat maka diduga dapat berakibat laba bank turun dan sebaliknya.

Industri jasa perbankan merupakan industri yang besar pengaruhnya di sektor keuangan. Tetapi masih terdapat kelemahan yaitu belum maksimal dalam mempertahankan kinerjanya untuk tetap baik. Bank Perkreditan Rakyat yang diteliti ini cukup unik karena keterbatasannya yang hanya menghimpun simpanan dan memberikan pinjaman ke masyarakat. Tidak seperti Bank Umum yang mempunyai cakupan kegiatan perbankan yang lebih luas, kondisi ini harus dihadapi oleh BPR untuk tetap bisa bertahan dan mampu bersaing. Karena satusatunya kegiatan menyalurkan dana ke masyarakat yang diijinkan untuk dilakukan BPR hanya dalam bentuk kredit maka dibutuhkan untuk menjaga agar penyaluran kredit bisa tepat sasaran dan memenuhi kriteria kredit yang sehat. Kualitas asset yang harus benar-benar dijaga tetap baik dan sehat, dimana ukuran kualitas aktiva ini akan diukur dengan Aktiva Produktif Yang Dikualifikasikan, Kualitas Asset Produktif, Non Performing Loan. Pengelolaan kualitas aktiva yang tidak optimal akan berakibat pada tertundanya pendapatan bunga yang seharusnya diterima. Penelitian berfokus pada menguji pengaruh kualitas asset produktif bagi laba BPR di Indonesia.

Di Indonesia BPR mulai marak sejak tahun 1992 dimana keberadaan BPR ini diatur dalam Undang Undang Nomor 7 tahun 1992 mengenai Perbankan. Secara umum perkembangan BPR di Indonesia mengalami peningkatan, tetapi secara indikator kinerja mengalami penurunan. Perkembangan BPR meliputi jumlah BPR, jumlah aset. Sedangkan sebagai pembanding perkembangan BPR ini adalah perkembangan kinerja dengan menggunakan indikator Return on Assets dan Non Performing Loan.

Berdasarkan Statistik Perbankan Indonesia Vol 17 No 1 desember 2018, Bank Perkreditan Rakyat di Indonesia jumlahnya terjadi penurunan, yaitu pada tahun 2013 sebanyak 1.635 menjadi 1.597 pada tahun 2018, sehingga terdapat 38 Bank Perkreditan Rakyat yang sudah tidak beroperasional lagi. Dalam kurun waktu 6 (enam) tahun, jumlah tersebut termasuk jumlah yang cukup besar dengan 
rata-rata setiap tahun terdapat 6 (enam) BPR yang tidak beroperasional lagi.

Sementara itu perkembangan jumlah aset BPR di Indonesia yang mengalami peningkatan, tercatat dari tahun 2013 sebesar Rp. 77.376 juta menjadi Rp.135.693 juta pada tahun 2018. Jumlah aset BPR ini mengalami peningkatan sebesar Rp. 58.317 juta atau 75,37\% lebih besar dari tahun 2013. Perkembangan ini luar biasa meningkat tajam mengingat justru berbanding terbalik dengan jumlah BPR yang menurun. BPR yang masih beroperasional justru semakin mampu meningkatkan eksistensinya sehingga mampu meningkatkan jumlah aset secara keseluruhan.

Kegiatan perbankan tidak luput dari kegiatan pada masyarakat yaitu menghimpun simpanan berupa tabungan dan deposito dan memberikan pinjaman kepada masyarakat. Peningkatan jumlah simpanan BPR di Indonesia, tercatat pada tahun 2013 adalah Rp. 50.520 juta menjadi Rp. 91.956 juta pada tahun 2018. Terjadi peningkatan Rp. 41.436 juta atau 82,02\% lebih besar dari tahun 2013. Namun pada kenyataannya meskipun jumlah dana masyarakat yang berhasil dihimpun mengalami kenaikan tetapi jumlah bank Perkreditan Rakyat justru menurun karena dinyatakan pailit.

Terjadi kenaikan jumlah penyaluran kredit BPR di Indonesia, tercatat dari tahun 2013 yaitu Rp. 59.176 juta menjadi Rp. 98.220 juta pada tahun 2018 . Jumlah penyaluran kredit Bank Perkreditan Rakyat ini mengalami peningkatan sebesar Rp. 39.044 juta atau 65,98\% lebih besar dari tahun 2013. Namun demikian perkembangan ini tidak diikuti perkembangan kinerja yang memuaskan. Penilaian kinerja Bank Perkreditan Rakyat di Indonesia menggunakan 2 (dua) indikator kinerja yaitu NPL dan ROA .

Non Performing Loan atau NPL merupakan indikator kinerja Bank Perkreditan Rakyat dalam mengendalikan aktiva produktif yang macet. Tercatat rasio NPL tahun 2013 terus menerus mengalami peningkatan dari 4,41\% menjadi $6,374 \%$ pada tahun 2018. Kondisi ini menunjukkan kinerja yang kurang memuaskan, karena kenaikan jumlah kredit yang disalurkan tidak diikuti pengelolaan kredit yang sehat dan prinsip pudential banking kurang diterapkan dengan baik. Semakin meningkatnya rasio NPL diikuti dengan menurunnya laba 
yang diterima yang ditunjukkan pada rasio Return on Assets.

Studi empiris tentang kualitas asset ini dilakukan oleh Komarudin (2018) pada Bank Yang List di BEI) dengan variabel yang diteliti adalah rasio KAP, dan profitabilitas. Ternyata terhadap profitabilitas, kualitas aset produktif tidak berpengaruh signifikan pada bank di BEI tahun 2011-2013. Selanjutnya Novitasari, Afriyanto dan Nofrianty (2016) dalam penelitiannya pada PT. BRI (Persero) Tbk. Dihasilkan kualitas aktiva produktif berpengaruh tidak signifikan pada ROA. Akbar (2013) dalam penelitiannya yang memakai periode 2007 2011 pada Bank Umum Syariah di Indonesia hasilnya adalah terdapat pengaruh ukuran perusahaan yang signifikan dengan arah positif pada ROA, serta KAP dan likuiditas berpengaruh signifikan dengan arah negatif pada ROA, juga terbukti bahwa kecukupan modal berpengaruh dengan arah positif, tetapi tidak signifikan pada ROA.

Berdasarkan penelitian terdahulu dan fenomena pentingnya manajemen kualitas asset pada Bank Perkreditan Rakyat, maka penelitian ini mengambil topik tentang kualitas asset produktif yang mempengaruhi laba bank.

\subsection{Perumusan Masalah}

Penelitian yang berkesinambungan tentang kegiatan bank dibidang Manajemen Kualitas Aset masih menarik untuk diteliti terutama pada BPR serta pengaruhnya terhadap laba bank. Kualitas Aset Produktif di BPR diukur dengan rasio Aktiva Produktif Yang Diklasifikasikan selanjutnya disingkat APYD, rasio Aktiva Produktif Yang Diklasifikasikan Dibanding Aktiva Produktif selanjutnya disingkat APYDAP dan Non Performing Loan selanjutnya disingkat NPL. Sedangkan laba bank diukur dengan Return On Asset selanjutnya disingkat dengan ROA. Permasalahan yang diuji dirumuskan sebagai berikut:

a. Apakah APYD berpengaruh signifikan terhadap ROA pada BPR di Indonesia?

b. Apakah APYDAP berpengaruh signifikan terhadap ROA pada BPR di Indonesia?

c. Apakah NPL berpengaruh signifikan terhadap ROA pada BPR di Indonesia?

d. Apakah APYD, APYDAP dan NPL secara simultan berpengaruh signifikan terhadap ROA pada BPR di Indonesia? 


\subsection{Tujuan Penelitian}

a. Mendapatkan bukti adanya pengaruh APYD terhadap ROA pada BPR di Indonesia.

b. Mendapatkan bukti adanya pengaruh APYDAP terhadap ROA pada BPR di Indonesia.

c. Mendapatkan bukti adanya pengaruh NPL terhadap ROA pada BPR di Indonesia.

d. Mendapatkan bukti adanya pengaruh APYD, APYDAP dan NPL secara simultan terhadap ROA pada BPR di Indonesia.

\subsection{Hipotesis}

Hipotesis 1 : Diduga terdapat pengaruh APYD terhadap ROA yang signifikan pada BPR di Indonesia.

Hipotesis 2 : Diduga terdapat pengaruh APYDAP terhadap ROA yang signifikan pada BPR di Indonesia.

Hipotesis 3 : Diduga terdapat pengaruh NPL terhadap ROA yang signifikan pada BPR di Indonesia.

Hipotesis 4 : Diduga terdapat pengaruh APYD, APYDAP dan NPL secara simultan terhadap ROA yang signifikan pada BPR di Indonesia.

\section{Tinjauan Pustaka}

\subsection{Landasan Teori}

\section{Kualitas Aset Produktif}

Dendawijaya (2005:61) memberikan pengertian asset produktif adalah "seluruh aset dengan bentuk rupiah dan valas pada bank yang bertujuan untuk mendapatkan hasil yang sesuai peranannya”. Berdasarkan definisi tersebut, maka dijelaskan bahwa aset produktif adalah penempatan dana dalam bentuk rupiah dan valas bisa juga pada bank lain, pinjaman kepada pihak ke lain, warkat dan penanaman kepada pihak lain, tagihan lainnya, yang bertujuan memperoleh pendapatan dari penempatan dana itu. Dengan maksud lain bahwa penempatan modal ini dilakukan untuk memperoleh keuntungan. Bank berpendapat bahwa 
lebih baik jika aset yang disimpan diletakkan pada beragam investasi jadi bisa memberikan manfaat lain kepada bank selain pendapatan dari pemberian pinjaman.

\section{Komponen Aktiva Produktif}

Komponen aset produktif berupa pinjaman yang disalurkan, penyertaan pada lembaga keuangan bank lainnya, warkat dan penanaman, Siamat (2004) yaitu:

1) Pinjaman yang disalurkan

2) Penyertaan pada lembaga keuangan bank lainnya

3) Warkat

4) Penempatan

Aktiva yang diinginkan untuk memberikan manfaat pada bank terdiri dari berbagai jenis yang lebih beragam selain pinjaman yang disalurkan. Maka diantaranya bank juga dapat menyertakan modalnya pada bidang usaha lain yang menguntungkan.

\section{Aktiva Produktif Yang Diklasifikasikan (APYD)}

APYD yaitu kolektibilitas seluruh aset produktif pada BPR yang dapat memberikan pendapatan sesui dengan perannya yang bersumber dari modal BPR. Kolektibilitas yang dimaksud adalah penggolongan sebagai DPK (dalam pengawasan khusus), KL (kurang lancar), DR (diragukan) dan M (macet). Rasio APYD diperoleh dari perbandingan APYD dengan modal bank yaitu modal pelengkap dan modal inti. Perhitungan aktiva produktif yang diklasifikasikan dilakukan dengan memberikan bobot prosentase yaitu yang digolongkan pada :

1) DPK adalah $25 \%$ dari aktiva produktif

2) KL adalah $50 \%$ dari aktiva produktif

3) DR $75 \%$ dari aktiva produktif

4) $\mathrm{M}$ adalah $100 \%$ dari aktiva produktif

\section{Aktiva Produktif Yang Diklasifikasikan Dibanding Aktiva Produktif (APYDAP) \\ APYDAP yaitu kolektibilitas seluruh aset produktif pada BPR dalam mendapatkan manfaat yang sesuai dengan perannya dan bersumber dari jumlah aktiva produktif. Rasio APYDAP dihitung dengan perbandingan APYD dengan}


aktiva produktif.

\section{NPL (Non Performing Loan)}

Non Performing Loan yaitu jumlah pinjaman yang dikategorikan bermasalah, terdiri atas pinjaman dalam kategori KL (kurang lancar), DR (diragukan) dan M (macet). Rasio NPL diperoleh dari perbandingan total pinjaman disalurkan dengan total aktiva produktif pada BPR. Aset produktif yang dianggap bermasalah adalah aset produktif dengan kategori KL (kurang lancar), DR (diragukan) dan M (macet), sebelum dikurangi dengan PPAP.

\section{Laba Bank}

Laba adalah kelebihan penghasilan, atau harga jual diatas cost; setiap benefit keuangan dari praktek profesi, kegiatan komersial, atau transaksi pribadi (Kamus istilah akuntansi, 1985).

Menurut Sastradipoera dalam Gumayantika (2008), laba yaitu sisa jumlah sesudah pendapatan bank dikurangi dengan semua jenis biaya variabel dan biaya tetap, kelebihan pendapatan di atas biaya bank. Jadi digunakan untuk melihat lebih awal nilai semua penghasilan dan biaya. Laba juga menggambarkan kefektifan manajemen dalam mengendalikan bisnisnya dengan berhasil.

Manfaat laba bagi suatu bank dibagi dalam beberapa hal sebagai berikut:

a. Untuk survive. Bank memiliki tujuan utama yaitu menjaga keberlanjutan atau sutainbility dimana laba yang diperoleh hanya mampu untuk membayar operasional bank.

b. Untuk growth. Saat bank didirikan pasti dengan ekspetasi bank akan tumbuh menjadi bank yang berskala besar, dan dapat membuka kantor cabang di berbagai wilayah. Harapannya adalah agar dapat meningkatkan kesejahteraan sumber daya manusianya.

c. Melaksanakan corporate social responsibility. Bank merupakan salah satu agen pembangunan, jadi bank juga memiliki tanggung jawab sosial yaitu bermanfaat bagi masyarakat sekitarnya diantaranya adalah dengan kegiatan sosial yang bermanfaat.

\subsection{Studi Empiris}

Studi empiris sebagai kajian yang digunakan sebagai dasar pertimbangan 
topik pada penelitian ini ditentukan dari variabelnya serta hasilnya yang memperkuat atau mendukung teori.

Penelitian Aini (2013) pada Perusahaan Perbankan yang terdaftar di BEI) Tahun 2009-2011 menghasilkan CAR, dan Kualitas Aset Produktif berpengaruh pada perubahan laba, NIM tidak berpengaruh pada perubahan laba, LDR, NPL berpengaruh tidak signifikan pada perubahan laba.

Penelitian yang dilakukan Akbar (2013) pada Bank Umum Syariah di Indonesia Periode 2007-2011)", memberikan hasil ukuran perusahaan berpengaruh terhadap ROA, sedangkan Kualitas Aktiva Produktif (KAP) dan likuiditas berpengaruh terhadap ROA, kecukupan modal terbukti berpengaruh, tetapi tidak signifikan terhadap ROA.

Penelitian Dewi (2012) di Sektor Perbankan Go Publik Yang Terdaftar Di Bursa Efek Indonesia Tahun 2010-2012". Hasil penelitian adalah kredit bermasalah berpengaruh signifikan dan negatif terhadap profitabilitas bank dengan tingkat pengaruh yang sangat rendah dan kualitas aktiva produktif berpengaruh signifikan dan positif terhadap profitabilitas bank dengan tingkat pengaruh yang sangat rendah.

Penelitian Eman (2013) pada PT. Bank Tabungan Pensiunan Nasional, Tbk”. Hasil pengujian adalah bahwa secara bersama-sama KAP, NPL memiliki hubungan kausalitas signifikan terhadap ROA dan KAP mempunyai pengaruh signifikan terhadap ROA.

Komarudin (2018) pada Bank Yang List di BEI) dimana kualitas aktiva produktif dengan menggunakan rasio KAP, dan profitabilitas dengan menggunakan Return on Assets (ROA).

Miadalyani dan Dewi (2013) dengan penelitiannya di PT. Bank Pembangunan Daerah Bali Kantor Pusat Denpasar". Hasilnya LDR, LAR, CAR, dan kualitas aktiva produktif secara simultan berpengaruh signifikan terhadap profitabilitas. Uji parsial memberikan hasil bahwa LDR berpengaruh positif dan signifikan terhadap profitabilitas, LAR, CAR dan kualitas aktiva produktif berpengaruh negatif dan tidak signifikan terhadap profitabilitas. 
Novitasari (2016) dalam penelitiannya pada PT. BRI (persero) tbk. Hasilnya hubungan kedua variabel termasuk hubungan yang kuat dan dengan arah hubungan yang negatif atau tidak searah. Uji parsial menunjukkan bahwa variabel kualitas aktiva produktif berpengaruh tidak signifikan terhadap Return on Asset.

Penelitian Somantri (2017) pada Bank Umum Syariah”. Hasilnya menunjukkan bahwa risiko pembiayaan (NPF) dan dana pihak ketiga (DPK) tidak berpengaruh terhadap tingkat rentabilitas (NOM), sedangkan kualitas aktiva produktif (KAP), perputaran piutang (ART), dan volume pembiayaan (FDR) berpengaruh terhadap tingkat rentabilitas (NOM.

\section{Metode Penelitian}

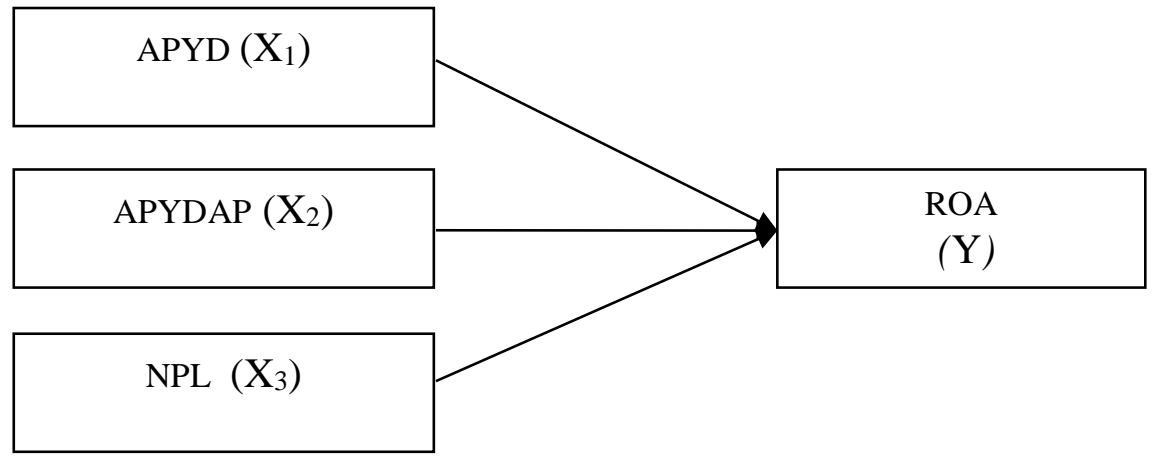

\section{Gambar 1}

Model Penelitian

Penelitian berjenis kuantitatif bertujuan mencari hubungan sebab akibat. Untuk menganalisis variabel bebas $(X)$ yaitu APYD, APYDAP dan NPL terhadap variabel terikat (Y) adalah laba bank ROA digunakan tehnik analisis regresi linier berganda. Tehnik ini akan menguji hipotesis yang menduga adanya pengaruh simultan dan parsial pada variabel bebas (X) yaitu APYD, APYDAP dan NPL terhadap variabel terikat (Y) adalah ROA.

Obyek penelitian yaitu data keuangan yang akan memberikan informasi tentang tentang rasio APYD, APYDAP, NPL dan ROA pada BPR di Indonesia. Pertimbangan dipilihnya obyek ini adalah:

a. BPR mempunyai berpengaruh cukup kuat terhadap perekonomian di Indonesia. 
b. BPR memiliki kemampuan bersaing dalam meraih kepercayaan masyarakat dengan bank umum.

c. BPR telah mempublikasikan laporan keuangan sesuai format yang ditentukan Bank Indonesia, sehingga dapat memenuhi kebutuhan data.

Jenis data sekunder karena berupa laporan keuangan BPR yang diperoleh dari Otoritas Jasa Keuangan. Datanya merupakan data kuantitatif karena berskala numerik atau angka, data berupa rasio APYD, APYDAP, NPL dan ROA.

Data yang digunakan juga berupa data pooling atau pooled time series yaitu perpaduan data runtut waktu dengan data silang tempat. Data pooling nya merupakan data yang dihimpun berdasar laporan keuangan BPR di Indonesia.

Publikasi laporan keuangan BPR digunakan sebagai populasi penelitian. Dengn metode purposive sampling ditentukan krriteria BPR yang menjadi sampel adalah :

a. BPR jenis konvensional di Indonesia.

b. Laporan keuangannya dipublikasikan di direktori Otoritas Jasa Keuangan secra aktif dan rutin.

c. Mempunyai informasi keuangan yang dibutuhkan yaitu laporan laba rugi neraca dan laporan lainnya.

d. Menerbitkan laporan keuangan triwulanan pada periode penelitian yaitu periode 2013 sd 2016.

Pada akhirnya sampel yang sesuai kriteria diperoleh sebanyak 400 laporan keuangan dari 100 BPR di Indonesia selama 4 (empat) periode triwulan.

\subsection{Variabel Penelitian}

Variabel terikatnya adalah Return On Asset (Y) dan variabel bebasnya adalah:

1) Aktiva Produktif Yang Dikualifikasikan $\left(\mathrm{X}_{1}\right)$ disingkat APYD

2) Aktiva Produktif Yang Dikualifikasikan Dibanding Aktiva Produktif $\left(\mathrm{X}_{2}\right)$ disingkat APYDAP

3) Non Performing Loan $\left(\mathrm{X}_{3}\right)$ disingkat NPL

\section{Aktiva Produktif Yang Dikualifikasikan (APYD)}

Yaitu kolektibilitas seluruh aktiva produktif pada BPR yang ditujukan untuk 
memperoleh pendapatan sesuai dengan perannya yang bersumber dari modal BPR. Kolektibilitas yang dimaksud adalah penggolongan DPK, KL, DR dan M. Rasio APYD diperoleh dari jumlah aktiva produktif yang diklasifikasikan yang dibandingkan dengan modal bank yang berupa modal inti dan pelengkap. Perhitungan aktiva produktif yang diklasifikasikan dilakukan dengan memberikan bobot prosentase pada golongan :

a. Dalam Pengawasan Khusus (DPK) adalah 25\% dari aktiva produktif

b. Kurang Lancar (KL) adalah $50 \%$ dari aktiva produktif

c. Diragukan (DR) adalah $75 \%$ dari aktiva produktif

d. Macet (M) adalah $100 \%$ dari aktiva produktif

\section{Aktiva Produktif Yang Dikualifikasikan Dibanding Aktiva Produktif (APYDAP)}

yaitu kolektibilitas seluruh aktiva produktif pada BPR untuk mendapatkan penghasilan sejalan perannya yang bersumber dari jumlah aktiva produktif. Rasio APYDAP dihitung dengan aktiva produktif yang diklasifikasikan ynag dibandingkan dengan aktiva produktif.

\section{Non Performing Loan (NPL)}

yaitu jumlah pinjaman yang telah disalurkan serta masuk dalam kategori bermasalah, terdiri dari pinjaman dengan kategori KL, DR dan M. Perhitungan rasio NPL adalah dengan membandingkan antara jumlah pinjaman yang diberikan dengan total aktiva produktif pada BPR. Aktiva produktif bermasalah adalah aktiva produktif yang memiliki kualitas KL, DR dan M, yang belum dikurangi PPAP.

\section{a. Return on Asssets}

yaitu suatu ukuran yang mempresentasikan kemampuan Bank Perkreditan Rakyat dalam memberikan laba atas asset. Rasio ROA dihitung dengn membandingkan antara laba sebelum pajak dengan rata-rata total aset.

\subsection{Instrumen Penelitian}

\section{Tabel 1}




\section{Instrumen Penelitian dan Skala Pengukuran}

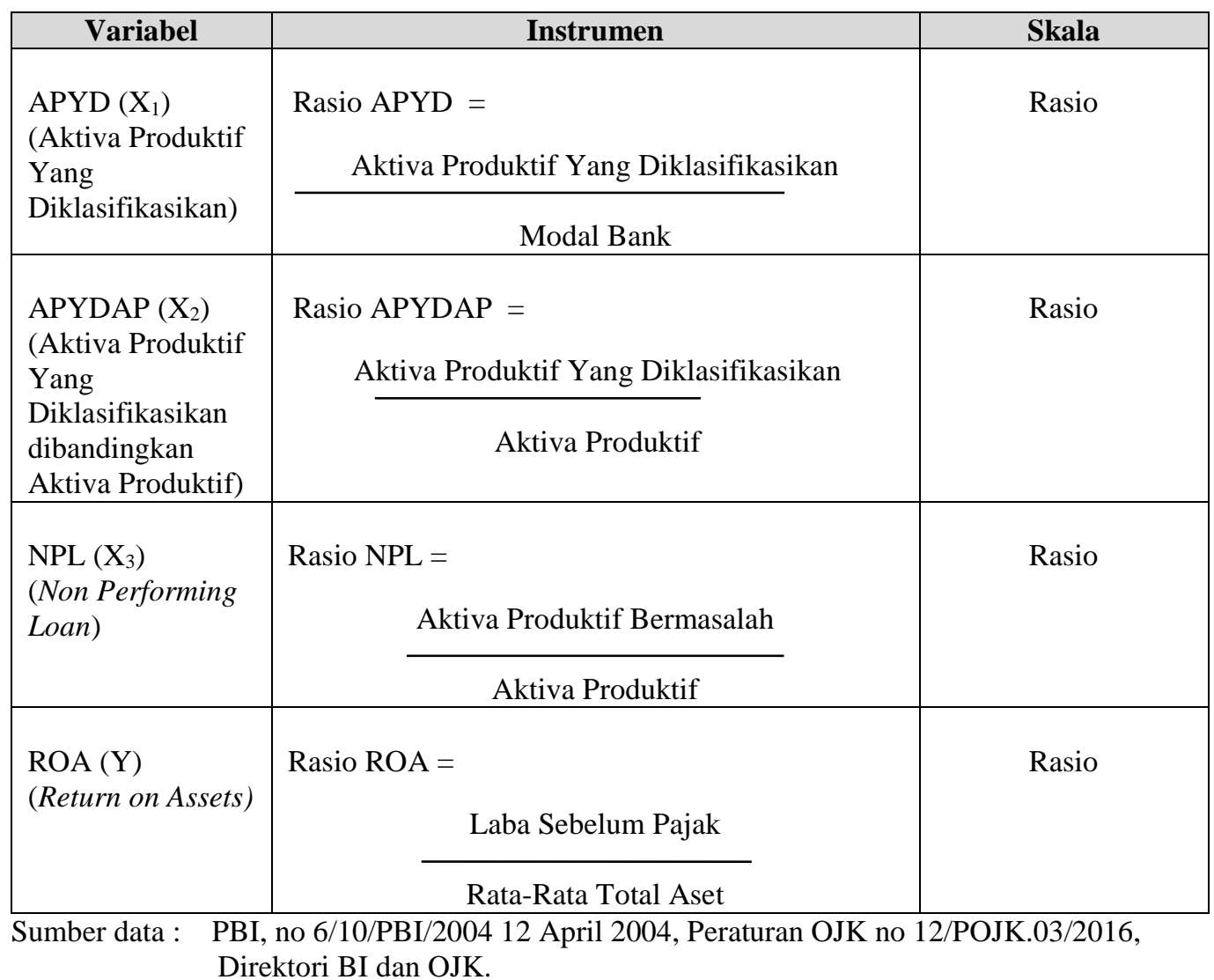

\subsection{Teknik Analisis Data}

Untuk menjawab hipotesis maka digunakan regresi linier berganda yang akan diproses dengan menggunakan aplikasi IBM SPSS 24.

Formula untuk regresi linier berganda sebagai berikut

$$
Y=a+b_{1} X_{1}+b_{2} X_{2}+b_{3} X_{3}+e
$$

Dimana :

$\mathrm{Y}=$ Return on Asset

$\mathrm{X}_{1}=\mathrm{APYD}$

$\mathrm{X}_{2}=\mathrm{APYDAP}$

$\mathrm{X}_{3}=$ Non Performing Loan

$\mathrm{a}=$ constanta

$\mathrm{b}=$ koefisien regresi variabel independen

$\mathrm{e}=$ error

\section{Pengujian Hipotesis}

\section{a. Uji t (Uji Parsial)}


Uji t dilakukan untuk melakukan pengujian secara parsial atas pengaruh parsial variabel bebas terhadap variabel terikat dengan menggunakan kriteria:

Hipotesis diterima jika $t_{\text {hitung }}<-t_{\text {tabel }}$ atau $t_{\text {hitung }}>t_{\text {tabel }}$

Hipotesis ditolak jika $-\mathrm{t}_{\text {tabel }} \leq \mathrm{t}_{\text {hitung }} \leq \mathrm{t}_{\text {tabel }}$

\section{b. Uji F (Uji Simultan)}

Uji F dilakukan untuk melakukan pengujian secara simultan variabel bebas terhadap variabel terikat dengan menggunakan kriteria:

Hipotesis diterima jika F hitung $\geq \mathrm{F}$ tabel

Hipotesis ditolak jika F hitung $<$ F tabel

\section{c. Koefisien Determinasi (R2)}

Digunakan nilai R Square untuk mengetahui nilai koefisien determinasi yang akan dipergunakan untuk menghitung kontribusi variabel independen terhadap variasi variabel terikat dalam bentuk prosentase (Santoso, 2012:355).

\section{Hasil Dan Pembahasan}

\subsection{Hasil Penelitian}

Tabel 2

Statistik Deskriptif Variabel Penelitian

\begin{tabular}{lcrrrr}
\hline Rasio & $\begin{array}{c}\mathbf{N} \\
\text { Statistic }\end{array}$ & $\begin{array}{c}\text { Min } \\
\text { Statistic }\end{array}$ & $\begin{array}{c}\text { Maks } \\
\text { Statistic }\end{array}$ & $\begin{array}{c}\text { Mean } \\
\text { Statistic }\end{array}$ & $\begin{array}{c}\text { Standar } \\
\text { Deviation }\end{array}$ \\
\hline APYD & 400 & 17,93 & 492,75 & 125,98 & 63,57 \\
\hline APYDAP & 400 & 0,00 & 307,00 & 5,52 & 16,24 \\
\hline NPL & 400 & 0,00 & 26,04 & 4,68 & 4,29 \\
\hline ROA & 400 & $-2,288$ & $1.325,00$ & 7,86 & 66,13 \\
\hline
\end{tabular}

Sumber : Data diolah, 2020.

Asumsi dasar regresi linier berganda harus terpenuhi terlebih dulu dimana menunjukkan hasil pengujian Kolmogorov Smirnov untuk menguji normalitas memiliki nilai sig 0,129>0,05 jadi data memenuhi kriteria normalitas sehingga model dinyatakan normal. Uji multikolinieritas hasilnya disajikan dalam tabel berikut:

Tabel 3

Hasil Pengujian Multikolinearitas

\begin{tabular}{llll}
\hline No. & Variabel & Tollerance & Nilai VIF \\
\hline
\end{tabular}




\begin{tabular}{lllll}
\hline 1. & APYD $\left(\mathrm{X}_{1}\right)$ & 0,990 & 1,011 & Terbebas Multikolinearitas \\
\hline 2. & APYDAP $\left(\mathrm{X}_{2}\right)$ & 0,977 & 1,023 & Terbebas Multikolinearitas \\
\hline 3. & NPL $\left(\mathrm{X}_{3}\right)$ & 0,968 & 1,033 & Terbebas Multikolinearitas \\
\hline
\end{tabular}

Sumber : Data diolah, 2020.

Uji multikolinieritas pada ketiga variabel independen memberikan nilai VIF di bawah 10 dengan tollerance diatas 0,1 . Jadi kesimpulannya variabel terbebas multikoinieritas. Sementara itu hasil uji heteroskedastisitas menggunakan scater plot menunjukkan pola tidak jelas dari titik-titik tersebut sehingga model regresi tidak memiliki gejala terjadi heteroskedastisitas. Sedangkan pengujian

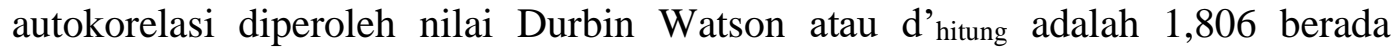
diantara 1,55 $<\mathrm{d}<2,46$ jadi tidak terjadi autokorelasi, oleh karena itu pengujian berikutnya bisa dilakukan sebab keseluruhan model sudah memenuhi kriteria asumsi dasar regresi linier berganda.

Hasil persamaan regresi linier berganda dengan Unstandardized Coefficient yaitu:

$$
\mathrm{Y}=3,398-0,026 \mathrm{X}_{1}+3,886 \mathrm{X}_{2}-2,927 \mathrm{X}_{3} \text {. }
$$

Selanjutnya dilakukan pengujian hipótesis, untuk melakukan pengujian $\mathrm{t}$ maka diperlukan hasil $t_{\text {tabel. }}$. Hasil $t_{\text {tabel }}$ dengan sig 5\% dan derajat kebebasan ( $\mathrm{n}$ 2 ) $=400-2=398$, didapatkan $t_{\text {tabel }}= \pm 1,9719$.

Hasil uji t atas variabel $\mathrm{X}_{1}$ yaitu Aktiva Produktif Yang Diklasifikasikan (APYD) diketahui nilai $t_{\text {hitung }}=-1,545$ dengan signifikansi 0,123 . Jadi $t$ hitung(1,545) berada diantara $\pm \mathrm{t}$ tabel $(1,9719)$. Dengan sig 0,123 di atas 0,05 maka kesimpulannya tidak terdapat pengaruh Aktiva Produktif Yang Diklasifikasikan (APYD) yang signifikan terhadap Return On Asset.

Hasil uji t atas variabel $\mathrm{X}_{2}$ yaitu Aktiva Produktif Yang Diklasifikasikan Dibandingkan Aktiva Produktif (APYDAP) diketahui nilai $t_{\text {hitung }}=58,148$ dengan sig 0,000. Jadi $\mathrm{t}$ hitung $(58,148)>\mathrm{t}$ tabel $(1,9719)$. Dengan sig 0,000 di bawah 0,05 maka kesimpulannya terdapat pengaruh Aktiva Produktif Yang Diklasifikasikan Dibandingkan Aktiva Produktif (APYDAP) yang signifikan terhadap Return On Asset.

Hasil uji t atas variabel $\mathrm{X}_{3}$ yaitu Non Performing Loan (NPL) diketahui nilai $t_{\text {hitung }}=-11,517$ dengan sig 0,000 . Jadi $t$ hitung $(-11,517)<-t_{\text {tabel }}(-1,9719)$. 
Dengan sig 0,000 di bawah sig 0,05 maka dapat disimpulkan bahwa terdapat pengaruh Non Performing Loan (NPL) yang signifikan terhadap Return On Asset.

Sementara itu hasil uji $\mathrm{F}$ diketahui nilai $\mathrm{F}_{\text {hitung }}=1133,533$ dengan signifikansi 0,000. Pada sig 5\% diperoleh $\mathrm{F}$ tabel sebesar 2,64. Jadi $\mathrm{F}$ hitung $(1133,533)>\mathrm{Ft}_{\text {tabel }}(2,64)$. Dengan sig 0,000 di bawah 0,05 maka disimpulkan bahwa terdapat pengaruh APYD, APYDAP dan NPL yang signifikan secara simultan terhadap Return On Asset.

Koefisien determinasi mempunyai nilai R Square sebesar 0,896. Jadi 89,6\% Return On Asset pada BPR di Indonesia bisa dijelaskan dipengaruhi oleh APYD, APYDAP dan NPL. Sedangkan sisanya yaitu 10,4\% Return On Asset dijelaskan oleh variabel lainnya yang belum di teliti di sini.

\subsection{Pembahasan}

\section{a. Pengaruh APYD Terhadap Return On Asset}

Diketahui bahwa Aktiva Produktif Yang Diklasifikasikan (APYD) tidak berpengaruh signifikan terhadap Return On Asset. Hasil ini mendukung penelitian Miadalyani dan Dewi (2013), Novitasari (2016), yang dalam penelitian mereka menyatakan terdapat pengaruh kuaitas aktiva produktif tetapi tidak signifikan terhadap profitabilitas. Tetapi penelitian ini hasilnya tidak sejalan dengan penelitian Aini (2013), Akbar (2013), Dewi (2012), Eman (2013), Somantri (2017), Komarudin (2018), yang dalam penelitian mereka menyatakan terdapat pengaruh signifikan kualitas aktiva produktif terhadap profitabilitas.

APYD yaitu kolektibilitas semua aktiva produktif yang dimiliki BPR untuk mendapatkan penghasilan yang bersumber dari modal BPR. Kolektibilitas yang dimaksud adalah penggolongan sebagai DPK, KL, DR dan M. Hasil penelitian bahwa APYD tidak berpengaruh signifikan terhadap Return On Asset dapat dijelaskan karena APYD yang dihitung adalah dibandingkan dengan modal yang dimiliki oleh BPR. Oleh karena itu atas pembanding modal ini maka tidak terdapat pengaruh APYD terhadap laba bank. BPR di Indonesia memang rata-rata mampu memenuhi kewajiban penyediaan modal minimum yang ditentukan. Namun demikian hal ini tidak bisa mengukur secara langsung atas kualitas aktiva produktifnya. 
Oleh karena itu sebaiknya manajemen BPR tetap memberikan perhatian terhadap aktiva produktif yang dikualifikasikan terutama dalam kewajibannya memenuhi penyediaan modal minimum yang ditentukan oleh OJK yaitu minimal $12 \%$ dari total asset yang dimiliki.

\section{b. Pengaruh APYDAP Terhadap Return On Asset}

Diketahui bahwa terdapat pengaruh APYDAP yang signifikan terhadap Return On Asset dengan arah hubungan yang positif. Penelitian ini hasilnya tidak sejalan hasil penelitian Miadalyani dan Dewi (2013), Novitasari (2016), yang dalam penelitian mereka menghasilkan terdapat pengaruh kuaitas aktiva produktif tetapi tidak signifikan terhadap profitabilitas. Tetapi hasil ini sejalan dengan penelitian Aini (2013), Akbar (2013), Dewi (2012), Eman (2013), Somantri (2017), Komarudin (2018), yang dalam penelitian mereka menyatakan kuaitas aktiva produktif berpengaruh signifikan terhadap profitabilitas.

APYDAP merupakan kolektibilitas semua aktiva produktif pada BPR dalam mendapatkan penghasilan sesuai dengan perannya yang bersumber dari jumlah aktiva produktif. Rasio APYDAP dihitung dari perbandingan aktiva produktif yang diklasifikasikan dengan aktiva produktif. Hasil penelitian yang menunjukkan kualitas aktiva produktif berpengaruh signifikan dengan arah positif terhadap Return On Asset yang berarti semakin meningkat jumlah kredit yang diklssifikasikan bermasalah maka semakin meningkat laba bank yang diukur dengan Return On Asset dan sebaliknya. APYDAP sudah menggolongkan kredit tunggakan 1 bulan ke atas sebagai kredit bermasalah namun demikian kredit dalam kategori Dalam Pengawasan Khusus (DPK) yaitu kredit dalam tunggakan 1 sampai dengan 3 bulan masih diakui sebagai pendapatan bunga karena sistem accrual basic yang digunakan pada Bank Perkreditan Rakyat. Oleh karena itu arah pengaruh yang positif ini menunjukkan bahwa yang terjadi pada Bank Perkreditan Rakyat ini kredit yang dianggap bermasalah banyak terjadi pada kredit dengan tunggakan 1 sampai dengan 3 bulan yang masih diakui sebagai pendapatan bank dan sebaliknya.

Oleh karena itu disarankan bahwa manajemen BPR tetap melakukan pengawasan atas kredit yang diklasifikasikan terutama pada kredit tunggakan 1 
sampai dengan 3 bulan dan lebih melakukan tindakan prinsip kehati hatian pada saat memberikan kredit ke masyarakat.

\section{c. Pengaruh Non Performing Loan Terhadap Return On Asset}

Diketahui bahwa terdapat pengaruh Non Performing Loan terhadap Return On Asset yang signifikan dengan arah hubungan yang negatif. Penjelasannya jika Non Performing Loan meningkat maka Return On Asset akan menurun dan sebaliknya semakin menurun Non Performing Loan maka Return On Asset akan meningkat. Hasil ini sejalan dengan hasil penelitian Aini (2013), Dewi (2012), Eman (2013) bahwa Non Performing Loan berpengaruh signifikan terhadap profitbailitas, tetapi hasilnya tidak sejalan dengan penelitian Somantri (2017) yang menyatakan bahwa risiko pembiayaan tidak berpengaruh signifikan terhadap profitabilitas.

Non Performing Loan adalah jumlah kredit yang telah diberikan dan masuk dalam kategori bermasalah, yaitu kredit pada kategori KL, DR dan M. Rasio Non Performing Loan dihitung dengan membandingkan jumlah kredit yang diberikan dengan total aset produktif pada BPR. Aktiva produktif bermasalah adalah aktiva produktif berkategori KL, DR dan M yang dihitung tidak dikurangi PPAP. Arah pengaruh Non Performing Loan terhadap Return On Asset adalh negative yang berarti semakin tinggi kredit bermasalah maka akan semakin rendah laba yang diterima dan sebaliknya. Berbeda dengan rasio kualitas aktiva produktif maka kredit yang masuk kategori Non Performing Loan tidak diakui sebagai pendapatan bagi bank. Bahkan kredit kategori dalam pengawasan khusus yang semula diakui sebagai pendapatan akan menjadi biaya pada saat masuk dalam kategori Non Performing Loan. Jadi bisa disimpulkan bahwa kredit yang dikategorikan NPL dianggap tidak memberikan pendapatan bagi bank.

Oleh karena itu disarankan pihak manajemen BPR bisa benar benar mengendalikan kreditnya tidak masuk kategori Non Performing Loan. Jika sudah terlanjur masuk pada kategori Non Performing Loan maka upaya penyelesaian secara intensif harus terus dilakukan dan memang yang lebih tepat adalah melakukan upaya pencegahan sebelum terjadi kredit bermasalah yaitu denagn menyalurkan kredit tepat sasaran dan dengan prinsip prudential banking.

\section{Kesimpulan}




\subsection{Kesimpulan}

Penelitian bertujuan menganalisis pengaruh kualitas asset produktif yang diproksikan dengan APYD, APYDAP dan NPL terhadap laba bank yitu ROA pada BPR di Indonesia.

a. Tidak terdapat pengaruh APYD terhadap ROA yang signifikan pada BPR di Indonesia.

b. Terdapat pengaruh APYDAP terhadap ROA yang signifikan pada BPR di Indonesia dengan arah positif yang berarti jika terjadi peningkatan APYDAP maka akan diikuti peningkatan pada ROA dan sebaliknya.

c. Terdapat pengaruh NPL terhadap ROA yang signifikan pada BPR di Indonesia dengan arah negatif yang berarti jika terjadi peningkatan NPL maka akan diikuti dengan penurunan ROA dan sebaliknya.

\subsection{Saran - Saran}

Penelitian ini diharapkan dapat bermanfaat bagi berbagai pihak, maka peneliti juga akan memberikan saran yang bisa dipertimbangkan dalam manajemen kualitas asset produtif pada BPR di Indonesia. Saran-saran sebagai berikut:

a. Manajemen kualitas asset produktif memunculkan risiko-risiko keuangan yang berasal dari internal BPR. Kondisi ini seharusnya lebih bisa diantisipasi oleh pihak manajemen BPR dalam mengelola kualitas asset produktif pada BPR.

b. APYDAP dan NPL ditemukan sebagai variabel yang berpengaruh signifikan terhadap ROA, oleh katena itu disarankan manajemen BPR tetap melakukan pengawasan atas kredit yang disalurkan dan lebih melakukan tindakan prudential banking pada saat menyalurkan kredit ke masyarakat.

c. Peneliti lainnya yang berminat untuk melakukan dengan pokok bahasan yang sama disarankan untuk melakukan penelitian pada BPR yang berprinsip syariah karena dengan prinsip yang berbeda maka ada kemungkinan bisa memberikan hasil yang berbeda yang berbeda bagi BPR di Indonesia.

d. Perlu dipertimbangkan risiko aspek operasional dan manajemen terkait dengan keseluruhan proses bisnis bank dan potensi dampaknya terhadap kepatuhan pada kebijakan dan prosedur bank, sistem dan teknologi internal, keamanan 
informasi, tindakan salah manajemen dan kecurangan, dan masalah kelangsungan bisnis. Aspek lain dari risiko operasional mencakup perencanaan strategis, tata kelola dan struktur organisasi bank, manajemen karir staf dan sumber daya internal, pengembangan produk dan pengetahuan, dan pendekatan pelanggan.

\section{DAFTAR PUSTAKA}

Aini, N. (2013). pengaruh CAR, NIM, LDR, NPL, BOPO, dan kualitas aktiva produktifterhadap perubahan laba (Studi Empiris Pada Perusahaan Perbankan yang terdaftar di BEI) Tahun 2009-2011. Dinamika Akuntansi Keuangan dan Perbankan, 2(1).

Akbar, D. A. (2013). Analisis pengaruh ukuran perusahaan, kecukupan modal, kualitas aktiva produktif (KAP) dan likuiditas terhadap kinerja keuangan. Jurnal Ilmiah STIE MDP, 3(1), 66-82.

Dewi, C. S. (2012). Pengaruh Kredit Bermasalah Dan Kualitas Aktiva Produktif Terhadap Profitabilitas Bank Pada Sektor Perbankan Go Publik Yang Terdaftar Di Bursa Efek Indonesia Tahun 2010-2012. Universitas Komputer Indonesia.

Eman, G. M. I. (2013). Pengaruh Kualitas Aktiva Produktif Dan Kredit Bermasalah Terhadap Profitabilitas PT. Bank Tabungan Pensiunan Nasional, Tbk. Jurnal Ilmu Administrasi (JIA), 9(3).

Faisal, A. M., \& Drs, M. M. (2003). Manajemen Perbankan (Teknik Analisis Kinerja Keuangan Bank). Malang: UMM.

Ghozali, I. (2013). Aplikasi Analisis Multivariat dengan Program IBM SPSS 21. Edisi 7, Penerbit Universitas Diponegoro, Semarang. Quarterly Journal of Economics, 128, 1547-1584.

Indonesia, B. (2004). Peraturan Bank Indonesia nomor: 6/10/PBI/2004 tentang sistem penilaian tingkat kesehatan bank umum. Peraturan bank Indonesia.

Kasmir. (2016). Bank dan Lembaga Keuangan Lainnya. cet. Ke-14. Jakarta: Raja Grafindo Persada) 
Komarudin, M. N. (2018). Pengaruh Kualitas Aktiva Produktif Terhadap Profitabilitas Bank (Studi Kasus Pada Bank Yang List di Bursa Efek Indonesia). Indonesian Journal of Strategic Management, 1(2).

Kuncoro. Mudrajad. (2007). Metode Kuantitatif. Yogyakarta : Unit Penerbit dan Percetakan (UPP) STIM YKPN.

Lukas, S. A. (2009). Statistika untuk bisnis dan ekonomi. Yogyakarta: Andi offset.

Miadalyni, D. \& Dewi, S. K. S. (2013). Pengaruh Loan To Deposit Ratio, Loan To Asset Ratio, Capital Adequacy Ratio Dan Kualitas Aktiva Produktif Terhadap Profitabilitas Pada Pt Bank Pembangunan Daerah Bali Kantor Pusat Denpasar. E-Jurnal Manajemen, 2(12).

Novitasari. R. (2016). Pengaruh Kualitas Aktiva Produktif Terhadap Return on Asset Pada PT. Bank Rakyat Indonesia (Persero) Tbk. Jurnal Mahasiswa Prodi Akuntansi Fakultas Ekonomi, 2(2).

Somantri. Y. F. (2017). Pengaruh Risiko Pembiayaan, Kualitas Aktiva Produktif, Dana Pihak Ketiga, dan Volume Pembiayaan Terhadap Tingkat Rentabilitas Pada Bank Umum Syariah. Jurnal Ekonomi Universitas Perjuangan, 1 .

Van Horne. J. C., \& Wachowicz. J. M. (2005). Fundamentals of Financial Management. Pearson Education. 